\title{
Tissue culture optimization for Lallementia royleana L. an important medicinal plant ${ }^{1}$
}

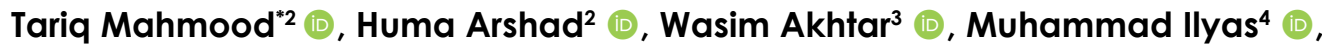 \\ Tariq Habib $^{3}$ (D), Zabta K. Shinwari ${ }^{2}$ (C)
}

\author{
'Part of M. Phil Dissertation of the second author Department of Plant Sciences, Quaid-i-Azam University, Islamabad, Pakistan \\ ${ }^{2}$ Department of Plant Sciences, Quaid-i-Azam University, Islamabad, Pakistan \\ ${ }^{3}$ Department of Botany, University of Azad Jammu and Kashmir Muzaffarabad, Pakistan \\ ${ }^{4}$ Department of Botany, University of Swabi KP, Pakistan \\ *Corresponding author: tmahmood.qau@gmail.com
}

Recebido em 04.X.2019

Aceito em 26.XI.2020

DOI 10.21826/2446-82312021v76e2021009

\begin{abstract}
This study was designed to develop an efficient protocol for Lallementia royleana in vitro culturing and to analyze the effect of various hormones on its culturing ability. The indirect organogenesis and its callogenetic ability were evaluated; with the best (100\%) results with $1 \mathrm{mg} \mathrm{L^{-1 }}$ of benzyl aminopurine (BAP) and $2 \mathrm{mg} \mathrm{L}^{-1}$ of indole acetic acid (IAA) combination. In direct regeneration, leave petioles, nodes and internodes explants were cultured for shooting on various concentrations of BAP and kinetin (KIN). Maximum shooting $(80 \%)$ was obtained from nodal parts with $1.0 \mathrm{mg} \mathrm{L}^{-1}$ of BAP and $0.5 \mathrm{mg} \mathrm{L}^{-1}$ of KIN. Similarly, the best in vitro rooting (24 roots) was achieved with $1 \mathrm{mg} \mathrm{L}^{-1}$ naphthalene acetic acid (NAA). Lallementia royleana showed higher regeneration through direct regeneration than callogenesis. Significant variability $(p=0.002625)$ among callus induction, plant parts and hormonal combinations were observed. The node and internode explants showed observable callus responses in combinations of 2, 4-Dichlorophenoxyacetic acid (2,4-D) with NAA, and BAP with IAA.
\end{abstract}

Keywords: in vitro culture, micropropagation, shooting

RESUMO - Otimização da cultura de tecidos para Lallementia royleana L. uma importante planta medicinal. O estudo foi realizado para desenvolver um protocolo eficiente para a cultura in vitro de Lallementia royleana e para analisar o efeito de vários hormônios em sua capacidade de cultura. Na organogênese indireta, sua capacidade calogenética foi avaliada com os melhores resultados (100\%) com $1 \mathrm{mg} \mathrm{L}^{-1}$ de benzil aminopurina (BAP) e $2 \mathrm{mg} \mathrm{L}^{-1}$ e combinação de ácido indolacético (IAA). Na regeneração indireta, explantes de pecíolo de folhas, nós e entrenós foram cultivados para filmagem em várias concentrações de BAP e cinetina (KIN). O valor máximo (80\%) foi obtido das partes nodais com 1,0 $\mathrm{mg} \mathrm{L}^{-1}$ de BAP e $0,5 \mathrm{mg} \mathrm{L}^{-1}$ de KIN. Da mesma forma, o melhor enraizamento in vitro (24 raízes) foi obtido com $1 \mathrm{mg} \mathrm{L}^{-1}$ de ácido naftaleno acético (NAA). $L$. royleana apresentou maior regeneração por regeneração direta do que por calogênese. Observou-se variabilidade significativa $(p=0,002625)$ entre indução de calos, partes de plantas e combinações hormonais. Os explantes de nódulos e internódios apresentaram respostas observáveis de calos em combinações de ácido 2, 4-diclorofenoxiacético (2,4-D) com NAA e BAP com IAA.

Palavras-chave: cultura in vitro, micropropagação, tiro

\section{INTRODUCTION}

The growing global demand for traditional medicinal plants has made large-scale commercial cultivation and genetic improvement imperative. Lallementia royleana $\mathrm{L}$. is one such plant belonging to the Lamiaceae with unlimited therapeutic potential. Due to its mucilaginous nature of seeds, it is widely used in the preparation of general tonics, expectorants and aphrodisiac medicines. It also serves as a vital remedy for several hepatic, renal and neural diseases (Bakhtiar et al. 2016). It's seeds provide relief in abscesses, inflammation and gastrointestinal problems (Abdulrasool et al. 2017), while its leaves possess antiemetic activity (Mangena et al. 2015). The seeds are also used to treat flatulence and constipation due to its cooling, sedative and diuretic properties. Its extensive swelling property make it valuable medicine for curing pain, bursting of boils and also as a super-disintegrant in the formulation of nimesulideoro dispersible tablets (Mahdieh et al. 2015). It also reduced serum cholesterol and triglyceride levels (Dode et al. 2003). Recently, a water soluble gum from $L$. royleana seeds was shown to have rheological properties (Pourebad et al. 2015). Economically, it is cultivated in different regions of Europe, Western Asia, Pakistan, Turkey, Iran and India for its mucilaginous seeds that occupy a special place in traditional medicine for curing many ailments (Abdulrasool et al. 2017).

In the Lamiaceae, seeds are the conventional method of propagation. However, poor seed viability, seasonal dependency and low germination rates $(<10 \%)$ potentially 
restricts its propagation (Razavi et al. 2016). Poor conservation policies and increased environmental changes may pose serious threats to this important plant. In this respect, in vitro culturing not only provides a method of mass propagation of disease-free plants it also provides a baseline for genetic engineering and somaclonal variation which may produce genetically stable variants for isolating agronomically important traits (Hossain et al. 2016). Previously, various members of the Lamiaceae were in vitro cultured from diverse organs and acclimatized. These included Salvia nemorosa L. (shoot tips, leaves) (Samantaray et al. 2013), Ocimum basilicum L. (Saker et al. 2000), Mentha viridis L. (nodal, shoot tips) (Ploetz et al. 2002), O. sanctum L. (leaves roots) (Kubis et al. 2003), O. gratissimum L. (nodal explant) (Razavi et al. 2016) and Vitex trifolia L. (Samantaray et al. 2013). However, until now, no report regarding in vitro culturing of L. royleana is available.

Generally, in vitro culturing is effective in producing clones and generating elite genotypes through organogenic differentiation for attaining superior characters. However, tissue culturing may create the risk of somaclonal variation due to genetic mutation or changes in epigenetic markers among the sub-clones of parental lines and its unpredictable nature seriously limits the utility of micropropagation systems (Krishna et al. 2016, Samantaray et al. 2013). So, keeping in view the medicinal and economic importance of $L$. royleana, the significance of in vitro culturing and its impacts on modern biotechnology, the current study was designed to develop an efficient protocol for in vitro culturing via direct and indirect organogenesis and to analyze the effect of various hormones on its culturing ability.

\section{MATERIALS AND METHODS}

\section{Seeds sterilization and inoculation}

Fresh seeds of $L$. royleana were soaked in distilled water for 12 hours. Mucilaginous coatings were removed by rubbing in folds of filter papers followed by treatment with $70 \%$ ethanol for 5 minutes and then with $25 \%$ commercial bleach for 15 minutes. Finally, seeds were washed three times with distilled water to remove any residual bleach and cultured on (Murashige and Skoog 1962) MS media by adding $30 \mathrm{~g} \mathrm{~L}^{-1}$ sucrose, with $\mathrm{pH}$ 5.8. Agar was added in concentration of $2 \mathrm{~g} \mathrm{~L}^{-1}$ and finally autoclaved at $121^{\circ} \mathrm{C}$ with 15 psi pressure. Germination occurred within two weeks of inoculation and five-week-old plants were used as an explant source.

\section{Indirect regeneration - Callogenesis}

Nodes, internodes and leaves were used as an explant source for callus induction using full strength MS media supplemented with various combination of indole acetic acid (IAA), NAA, benzyle aminopurine (BAP) and 2, 4-D hormones. Thirteen different callus inducing media (CIM) were tested (Supplementary table 1) and calli on each media were observed throughout the experiment for five weeks and the data was recorded. CIM 0 was simple MS without any hormone. CIM1, CIM2 and CIM3 were fortified with 0.5 , 1 and $2 \mathrm{mg} \mathrm{L}^{-1} \mathrm{NAA}$, respectively. CIM4, CIM5 and CIM6 were added with $0.5,1$ and $2 \mathrm{mg} \mathrm{L}^{-1}$ IAA, respectively. CIM7, CIM8 and CIM9 were provided with $0.5,1$ and 2 $\mathrm{mg} \mathrm{L}^{-1}$ BAP, respectively. CIM10 and CIM11 were added with combination of $0.5 \mathrm{mg} \mathrm{L}^{-1} \mathrm{BAP}+1 \mathrm{mg} \mathrm{L}^{-1} \mathrm{IAA}$ and $1 \mathrm{mg} \mathrm{L}^{-1} \mathrm{BAP}+2 \mathrm{mg} \mathrm{L}^{-1}$ IAA, respectively. While CIM12 and CIM13 were fortified with $2 \mathrm{mg} \mathrm{L}^{-1} 2,4-\mathrm{D}+1 \mathrm{mg} \mathrm{L}^{-1}$ NAA and $1 \mathrm{mg} \mathrm{L}^{-1} 2,4-\mathrm{D}+2 \mathrm{mg} \mathrm{L}^{-1}$ NAA, respectively. All CIM were tested for node, internode, and leaf explants.

\section{Direct regeneration}

\section{Shooting media}

For direct regeneration, explants (nodes, internodes, leaves and petioles) were first inoculated on nine different shooting media (S) supplemented with various concentrations of BAP and Kinetin (Kin). S0 was simple MS without any hormone. S1, S2, S3 and S4 were supplemented with $0.5,1,2$ and $4 \mathrm{mg} \mathrm{L}^{-1}$ BAP, respectively. While S5, S6, S7 and S8 were fortified with $0.5,1,2$ and $4 \mathrm{mg} \mathrm{L}^{-1}$ Kin respectively (Supplementary table 3 ). The plants were placed in a growth chamber for shoot initiation which began after two weeks of incubation.

\section{Rooting media}

After shoot formation, plants were transferred to seven different rooting media $(\mathrm{R})$ supplemented with various concentrations of NAA and IAA. R0 was simple MS without any hormone. R1, R2 and R3 were supplemented with $0.5,1$ and $2 \mathrm{mg} \mathrm{L}^{-1} \mathrm{NAA}$, respectively. While R4, $\mathrm{R} 5$ and R6 were fortified with $0.5,1$ and $2 \mathrm{mg} \mathrm{L}^{-1}$ IAA (Supplementary table 5).

\section{Sub-culturing and Maintenance}

For callus induction, the cultures were kept under 16 hours photoperiod, $55+5 \%$ relative humidity at $25-26^{\circ} \mathrm{C}$ and the light intensity was maintained at 1000 lux inside the growth chamber. The explants were transferred to fresh media after 25-30 days.

\section{Statistics}

Various parameters like number of shoots, shoot length, number of root, root length, shooting and rooting percentage were recorded for each plant on shooting and rooting media. Least significant difference (LSD) was calculated using Excel 2010. Analysis of variance (ANOVA) was performed for callus induction, plant parts and different hormonal combination using Paleontological Statistics Software (PAST) (Hammer et al. 2001). Principal component analysis (PCA) was conducted using callus induction responses of nodes, internodes and leaves explants and hormonal 
combination. Similarly, shooting and rooting responses were also statistically analyzed. $P$ (same) value $<0.05$ was considered as observable in ANOVA. $P$ value was also calculated using PAST normality test and values $<0.05^{*}$ considered as statically significant and $<0.01 * *$ as statistically highly significant.

\section{RESULTS}

Regeneration of L. royleana took place either indirectly through callogenesis or directly by skipping the callus stage and passing the plant through various stages of shooting and rooting (Fig. 1).

\section{Indirect Regeneration - Callogenesis}

Thirteen different media (Supplementary table 1) with various combinations of auxin (IAA, NAA) and cytokinin (BAP) were tested for their callogenic abilities of which nine were successful with an (average of 69\%) (Fig. 2A). Comparatively, nodal segments were the most efficient source for callus induction as compared to internode and leaves (Fig. 2 B). Calli from leaves were only found on media CIM12. The observation regarding the response of each part of the plant on different media up to 5 weeks is given in supplementary table 1 . Media containing no growth regulators (CIM0) did not support the development of any callus. Maximum callus induction (100\%) with good quality and texture was observed on CIM11 (BAP 1, IAA $2 \mathrm{mg} \mathrm{L}^{-1}$ ) using nodes and internodes as explants. Calli of good quality were also observed on other media but due to their small size and degeneration after three weeks, they were not used further for organogenesis.

The comparison of auxin and cytokinin in callus induction showed that auxin (IAA, NAA) alone is more effective in callus induction. Auxin induced callogenetic activity on CIM1 and CIM6 using nodes and on CIM2, CIM3 and CIM4 using internodes as explant sources. However, effective activity (90\%) was shown on CIM3 containing $2.0 \mathrm{mg} \mathrm{L}^{-1}$ of NAA, which resulted in calli of variable texture and color as compared with CIM1, CIM4 and CIM5 (Supplementary table 1). Cytokinins (BAP) did not promote callogenic activity in L royleana as CIM7 (BAP $0.5 \mathrm{mg} \mathrm{L}^{-1}$ ), CIM8 (BAP $1.0 \mathrm{mg} \mathrm{L}^{-1}$ ) and CIM9 (BAP $2.0 \mathrm{mg} \mathrm{L}^{-1}$ ) did not induce calli from any explants. Conversely, direct regeneration was observed at these concentrations of BAP. However, callus induction media with combinations of auxins and cytokinin i.e., CIM10, CIM11, CIM12 and CIM13 were the most suitable with $90 \%$ callus induction in case of nodal explants (CIM12, CIM13). However, the calli were of small size and fragile and survived only for three weeks.
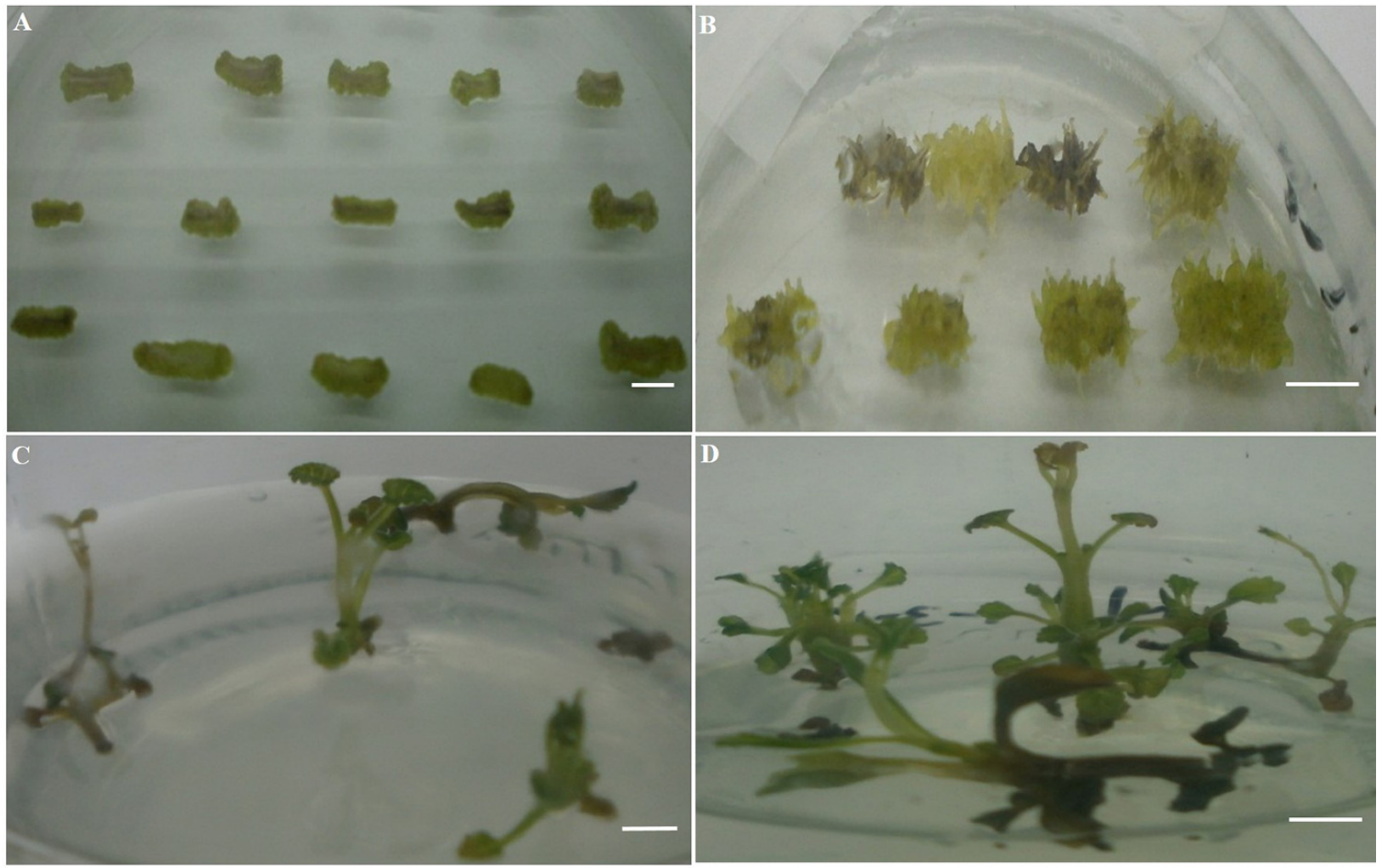

Figure 1. A-D. Various stages of regeneration of L. roylana using direct and indirect regeneration. A. Nodal explants inoculated on callus (2mm) induction media 11 (CIM11) supplemented with combination of $1 \mathrm{mg} \mathrm{L}^{-1} \mathrm{BAP}+2 \mathrm{mg} \mathrm{L}^{-1} \mathrm{IAA}$ in MS) during indirect regeneration; B. Nodal explant of CIM11 showing mature calli $(5 \mathrm{~mm})$ after 3 weeks; C. Shooting response of nodal explants on shooting $(5 \mathrm{~mm}) 2$ (S2) media supplemented with $1.0 \mathrm{mg} \mathrm{L}^{-1}$ BAP after five weeks; D. Rooting of S2 differentiated shoots $(5 \mathrm{~mm})$ on rooting 2 (R2) media supplemented with $1.0 \mathrm{mg} \mathrm{L}^{-1} \mathrm{NAA}_{\text {after }}$ 4 weeks. $\mathrm{CIM}=$ Callus inducing media, $\mathrm{S}=$ Shooting media 


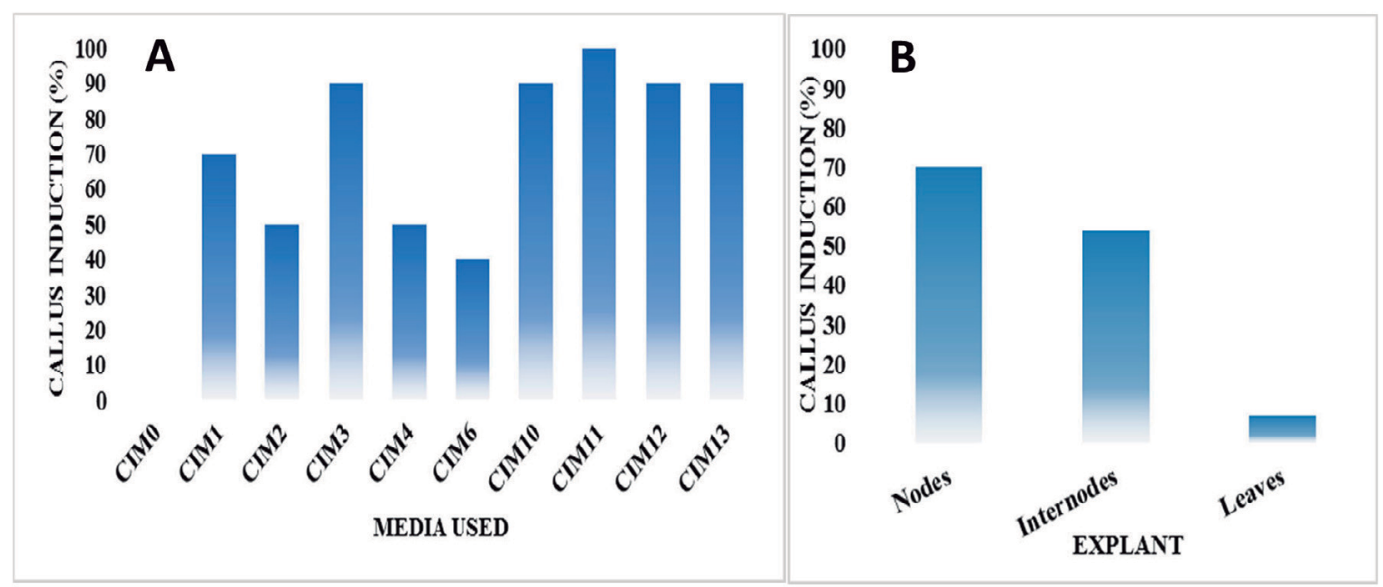

Figure 2. A-B. These graphs show the callus induction percentage (\%) on different CIM used for callogenesis and callus induction \% of nodes, internodes and leaf explants used. A. Percentage callus induction of L. royleana on CIM supplemented with different concentrations of NAA, IAA, BAP, combination of BAP with IAA and 2,4-D with NAA. CIM0 (no hormone), CIM1 (0.5 mg L-1 NAA), CIM2 (1 mg L $\left.\mathrm{L}^{-1} \mathrm{NAA}\right), \mathrm{CIM}^{-1}$ (2 mg L-1 NAA), CIM4 (0.5 mg L-1 IAA), CIM5 (1 mg L-1 IAA), CIM6 (2 mg L-1 IAA), CIM7 (0.5 mg L-1 BAP), CIM8 (1 mg L-1 BAP), CIM9 (2 mg L ${ }^{-1}$ BAP), CIM10 (0.5 mg L-1 BAP $1 \mathrm{mg} \mathrm{L}^{-1}$ IAA), CIM11 ( $1 \mathrm{mg} \mathrm{L}^{-1} \mathrm{BAP}+2 \mathrm{mg} \mathrm{L}^{-1}$ IAA), CIM12 (2 mg L-1 2, 4-D + $\left.1 \mathrm{mg} \mathrm{L}^{-1} \mathrm{NAA}\right), \mathrm{CIM}^{-13}\left(1 \mathrm{mg} \mathrm{L} \mathrm{L}^{-1} 2\right.$, 4-D $2 \mathrm{mg} \mathrm{L}^{-1} \mathrm{NAA}$ ); B. Different explants nodes, internodes and leaves are showing callus induction response of $70 \%, 54 \%$ and $7 \%$ respectively. $\mathrm{CIM}^{+}=$Callus inducing media

Statistical analysis of callus responses (\%) of nodes, internodes, and leaf explants on NAA, IAA, BAP, 2, 4-D and combinations (BAP + IAA and 2, 4-D + NAA) showed that calli responses in terms of ANOVA is significant with $p$ value of 0.002625 (Supplementary Table 2). PCA analysis showed that certain plant parts (nodes and internodes) and hormonal combinations (BAP + IAA and 2, 4 D + NAA) are more suitable for callus induction (Fig. $3 \mathrm{~A}$ ).

\section{Direct Regeneration}

\section{Shoot induction}

Nine different media supplemented with various combination of BAP and KIN were tested for shoot induction of which seven (S1, S2, S3, S4, S5, S6 and S8) gave results after two weeks of incubation (Supplementary Table 3). However, after five weeks, shoots formed and survived only on S2, S5, S6, and S8. Furthermore, no shoots was induced on $\mathrm{S} 0$ and $\mathrm{S} 7$ but the best shoots were observed on $\mathrm{S} 2$ supplemented with $1 \mathrm{mg} \mathrm{L}^{-1}$ of BAP which produced an average of 17 shoots per explant with an average length of $3.8 \mathrm{~cm}$. BAP was more effective at shoot induction but in addition to BAP, KIN also promoted shoot proliferation, as $60 \%$ shoot induction was observed on $\mathrm{S} 5$ supplemented with $0.5 \mathrm{mg} \mathrm{L}^{-1} \mathrm{KIN}$ but further increase in concentration reduced shooting up to $20 \%$ as found on $\mathrm{S} 6$ and $\mathrm{S} 8$ supplemented with 1.0 and $4.0 \mathrm{mg} \mathrm{L}^{-1}$ of KIN respectively (Figure 4A). It was observed that the effect of BAP and KIN on the average number of shoots and shoot length showed a negative effect on shoot number, but KIN alone has a positive effect on shoot length, at higher concentrations of KIN ( $\left.4.0 \mathrm{mg} \mathrm{L}^{-1}\right)$ the average shoot length increased up to $8.5 \mathrm{~cm}$ (Fig. $4 \mathrm{~B}, \mathrm{C}$ ). Among the various explants used (leaves, petioles, nodes, and internodes), shooting was induced only on nodal parts whereas internodes, leaves and petioles did not show any regeneration potential. Statistical analysis showed that BAP and KIN showed no observable effects on shooting with a $p$ (same) value of 0.841722 (Supplementary Table 4). Similarly, PCA analysis also showed BAP and KIN affect shooting quite differently as shown in the PCA scatter Fig. 3 B.

\section{Root induction}

Fully established shoots from S2 medium were separated and shifted to rooting media for root induction. Seven media with different concentration of auxins (NAA and IAA) were used (Supplementary Table 5). Media (R0) lacking any plant growth regulators failed to produce any roots. The maximum number of roots were induced on R2 producing an average of 24 roots per plant after two weeks of incubation while the maximum root length $(3.8 \mathrm{~cm})$ was observed on R4 (Fig. 5 A, B). It was observed that NAA was more effective at root induction (R2) while IAA has a role in increasing root length (R4). Analyzing the effect of rooting media on shoot induction showed that among all rooting media, R2, R3 and R4 caused an increase in number up to 35 shoots in addition to root induction (Fig. 6 A) whereas the maximum shoot length was observed on R3 medium $(5.8 \mathrm{~cm}$ ) (Fig $6 \mathrm{~B})$. NAA was found to be more effective in increasing shoot number and shoot length whereas IAA had a negative effect on both shoot length and number. However, R1 medium with $0.5 \mathrm{mg}$ $\mathrm{L}^{-1}$ NAA had a minimal effect on both shoot length and number. ANOVA showed that that NAA and IAA had no observable effects on rooting ( $p=0.204568)$ as $p$ value is greater than 0.05 (Supplementary Table 6). Similarly, PCA analysis also showed that NAA and IAA affect rooting quite differently (Fig. $3 \mathrm{C}$ ). 

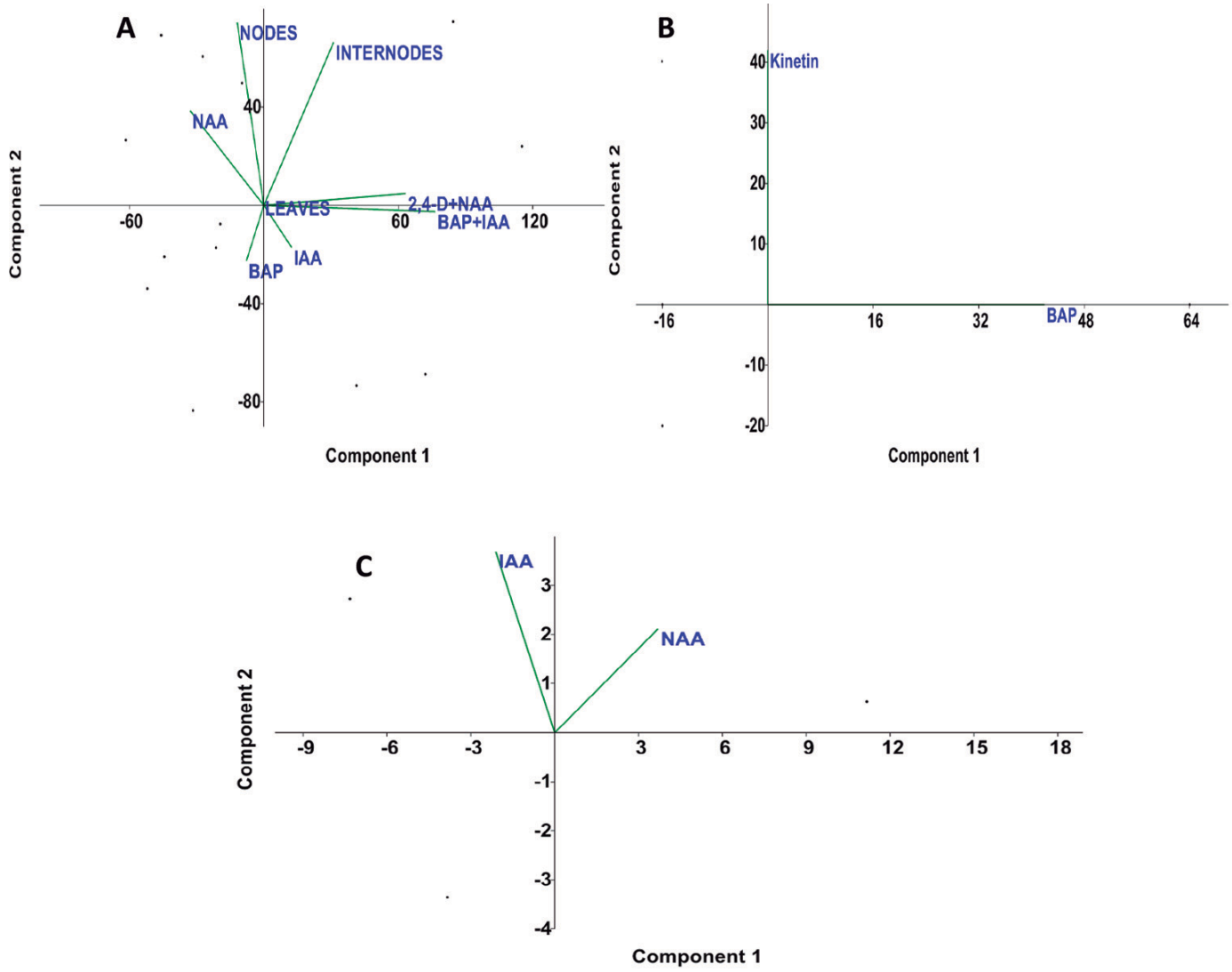

Figure 3. A-C. Principal components analysis (PCA) for calli induction $\%$ on CIM supplemented with different concentrations of NAA, IAA, BAP, combination of BAP with IAA and 2,4-D with NAA. Percentage of calli on MS media supplemented with NAA, IAA, BAP, BAP + IAA and 2, 4-D + NAA for nodes, internodes, and leaf explants; B. PCA analysis of shoot regeneration $\%$ on S media supplemented with different concentrations of BAP and Kin; C. PCA analysis of rooting $\%$ on R media supplemented with different concentrations of NAA and IAA. CIM $=$ Callus inducing media, $\mathrm{S}=$ Shooting media, $\mathrm{R}=$ rooting media

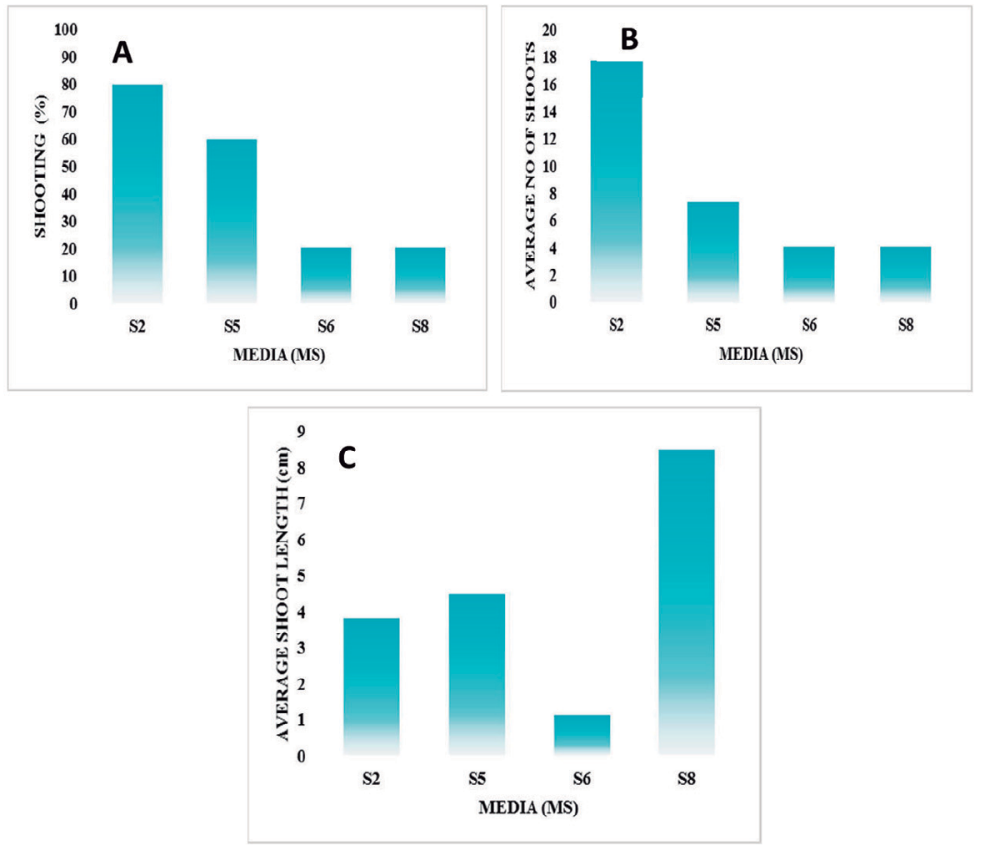

Figure 4. A-C. Graphs show the shooting response, number of shoot and shoot length on shooting media (S). A Percentage (\%) shooting response of explants on different S media supplemented with different concentration of BAP and Kin plant growth regulators. S0 = Simple MS without hormone, $\mathrm{S} 1=0.5 \mathrm{mg} \mathrm{L}^{-1} \mathrm{BAP}, \mathrm{S} 2=1.0 \mathrm{mg} \mathrm{L}^{-1} \mathrm{BAP}, \mathrm{S} 5=0.5 \mathrm{mg} \mathrm{L}^{-1} \mathrm{BAP}, 0.5 \mathrm{mg} \mathrm{L}^{-1} \mathrm{KIN}, \mathrm{S} 6=1.0 \mathrm{mg} \mathrm{L}^{-1} \mathrm{KIN}, \mathrm{S} 8=4.0 \mathrm{mg} \mathrm{L}^{-1} \mathrm{KIN}$; B. Effect of different $\mathrm{S}$ media on average number of shoots per regenerated plant; $\mathbf{C}$. Effect of different $\mathrm{S}$ media on average shoot length $(\mathrm{cm})$ per regenerated plant. $\mathrm{S}=$ Shooting media. 


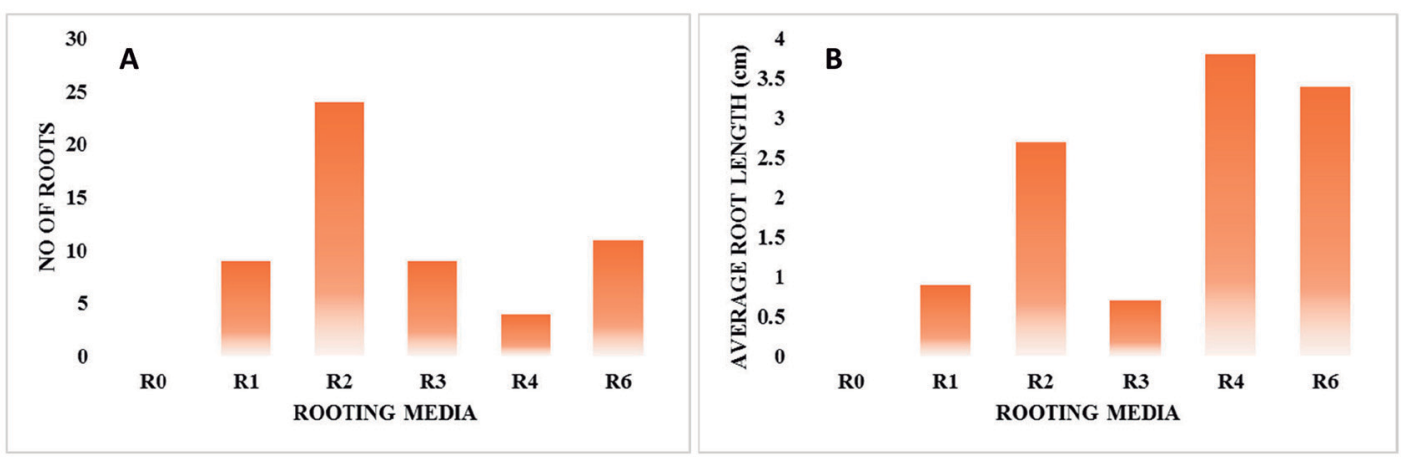

Figure 5. A-B. Graphs represent the average number of roots and root length of regenerated plants (from S2) on different rooting media (R) supplemented with different concentrations of NAA and IAA plant growth regulators. A. Number of roots on different R media; $B$. Average root length on different R media; $\mathrm{R} 1=0.5 \mathrm{mg} \mathrm{L}^{-1} \mathrm{NAA}, \mathrm{R} 2=1 \mathrm{mg} \mathrm{L}{ }^{-1} \mathrm{NAA}, \mathrm{R} 3=2 \mathrm{mg} \mathrm{L}^{-1} \mathrm{NAA}, \mathrm{R} 4=0.5 \mathrm{mg} \mathrm{L}^{-1} \mathrm{IAA}, \mathrm{R} 6=2 \mathrm{mg} \mathrm{L}^{-1}$ IAA. R= Rooting media.

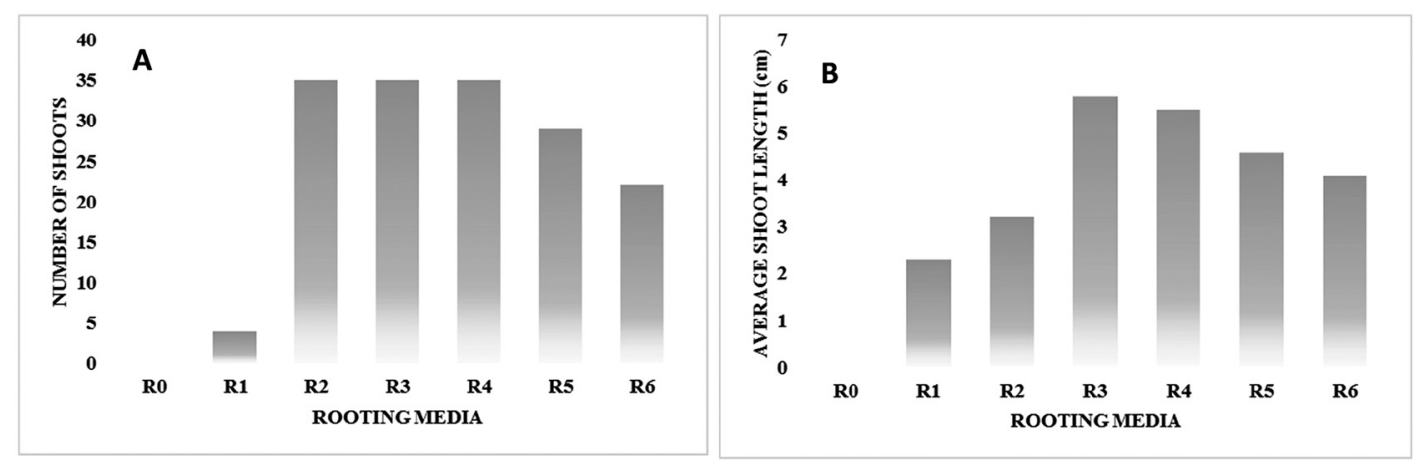

Figure 6. A-B. The effect of rooting media $(R)$ on shoot number and shoot length. R0: no growth regulator, $R 1=0.5 \mathrm{mg} \mathrm{L}^{-1} \mathrm{NAA}, \mathrm{R}^{2}=1 \mathrm{mg} \mathrm{L}{ }^{-1}$ NAA, R3 $=2 \mathrm{mg} \mathrm{L}^{-1} \mathrm{NAA}, \mathrm{R} 4=0.5 \mathrm{mg} \mathrm{L}^{-1}$ IAA, R5 $=1 \mathrm{mg} \mathrm{L}^{-1} 1, \mathrm{R} 6=2 \mathrm{mg} \mathrm{L}^{-1}$ IAA. A. Effect of NAA and IAA on number of shoots; B. Effect of NAA and IAA on shoot length $(\mathrm{cm}) . \mathrm{R}=$ Rooting media

\section{DISCUSSION}

\section{Indirect regeneration}

Lallementia royleana has poor callogenic ability but good quality calli can be obtained from its nodes using hormonal combinations of $1 \mathrm{mg} \mathrm{L}^{-1} \mathrm{BAP}$ and $2 \mathrm{mg} \mathrm{L}^{-1}$ IAA which is in accordance with the earlier study of Jatoi et al. (1999) for Lycopersicon esculentum L. As slightly more concentration of auxin promotes the callogenesis or proliferation by activating cell cycle re-entry through transcription factors (TFs). While cytokinin also aid in cell cycle progression (Ikeuchi et al. 2013). Auxin (NAA) alone was found more effective in callus induction than cytokinin as shown in culturing of Pluchea lanceolate (DC.) C.B. Clarke. (Arya et al. 2008) and Salvia canarienis L. (Mederos-Molina S 2004a). These results are contradictory to observations in L. iberica (Pourebad et al. 2015) where Thidiazuron (TDZ) was found to be more efficient in callogenesis than NAA and Indole-3-butyric acid (IBA). Normally TDZ triggered shooting by organogenesis while IBA promoted cellular multiplication at concentrations of 1 $\mathrm{mg} \mathrm{L}^{-1}$ in Hyssopus officinalis L. (Lamiaceae) (Toma et al.
2004). Overall, auxin was found to be callogenetic agent in the Lamiaceae family which promote callus formation through activation of different TFs (Ikeuchi et al. 2013).

In our experiments, the BAP and IAA combination induced $100 \%$ calli formation. This is comparable with different levels of BAP and NAA combination (low concentration) trigger cell cycle re-entry resulting callus induction of $O$. basilicum (Dode et al. 2003, Ikeuchi et al. 2013). Exogenious application of auxin alongwith cytokinin promote callus in many plant species (Ikeuchi et al. 2013, Skoog and Miller 1957). Similarly, cytokinin $(0.5 \mathrm{mg}$ $\left.\mathrm{L}^{-1} \mathrm{BAP}\right)$ in combination with auxin $\left(0.02 \mathrm{mg} \mathrm{L}^{-1} \mathrm{NAA}\right)$ resulted in maximal callus induction in L. iberica (M.Bieb) Fisch. \& C.A. Mey. (Ozdemir et al. 2014). However, Thymus persicus L. (Lamiaceae) generated calli on different concentrations of auxin alone or in combinations of $2 \mathrm{mg}$ $\mathrm{L}^{-1} \mathrm{NAA}$ and $0.5 \mathrm{mg} \mathrm{L}^{-1} \mathrm{Kin}$ resulting maximum (100\%) calli induction from internodes (Bakhtiar et al. 2016). $L$. iberica was reported to induce maximum calli on $4 \mathrm{mg} \mathrm{L}-1$ of 2, 4-D in combination with $1.5 \mathrm{mg} \mathrm{L}^{-1}$ of BAP (Razavi et al. 2017). Recently, Catharanthus roseus L. produced calli upon treatment of auxin and cytokinin combination (Rahman et al. 2019). 
However, the combined role of NAA and IAA was more effective in callus induction as reported for Quercus rubra L. (Krishna et al. 2016), O. americanum L. and $O$. sanctum L. (Pattnaik and Chand 1996) where auxins can trigger cell cycle re-entry through activation of wound induced TFs (Iwase et al. 2011). Nodes were found to be more effective for callogenesis than leaves and internodes. These results are in accordance with Salvia officinalis L. (Tawfik and Mohamed 2007) and Picrorhiza kurroa Royle ex Benth. (Mahajan et al. 2016) as nodal parts of plants possess more totipotency for culturing than leaves and inter nodes (Balilashaki et al. 2015). However, a limited callogenic ability was also observed in leaves which is similar to reports of $O$. basilicum (Gopi and Ponmurugan 2006), O. sanctum (Lim et al. 2009), Mentha piperita L. (Sujana and Naidu 2011) and broccoli leaves (Hossain et al. 2016).

\section{Direct regeneration}

In direct regeneration, BAP was the most effective hormone at inducing shoots $(80 \%)$. Cytokinin are very instrumental role in regeneration along with auxin through organogenesis and cell maturation (Hill and Schaller 2013). MS supplemented with a range of $0.5-3 \mathrm{mg} \mathrm{L}^{-1}$ BAP induced regeneration and shooting in $O$. sanctum (Singh and Sehgal 1999) which is quite similar to shooting e of L. royleana at $1 \mathrm{mg} \mathrm{L}^{-1}$ BAP. Similarly, in L. iberica the best shoot induction was observed on $0.5 \mathrm{mg} \mathrm{L}^{-1} \mathrm{BAP}$ (Ozdemir et al. 2014).

In the current study, L. royleana plantlets exhibited higher levels of shooting $(>80 \%)$ than observed in $O$. basilicum (Dode et al. 2003) (66\% shooting on $5 \mathrm{mg} \mathrm{L}^{-1}$ $\mathrm{BAP}+0.2 \mathrm{mg} \mathrm{L}^{-1} \mathrm{NAA}$ ) as BAP can trigger organogenesis differentially in different genus through kinase receptors (Hill and Schaller 2013). L. royleana shooting response is close to Mentha viridis L. ( $80 \%$ on $\left.3 \mathrm{mg} \mathrm{L}^{-1} \mathrm{BAP}\right)$ (Raja and Arockiasamy 2009) and T. persicus ( $96 \%$ internodes shooting, $2 \mathrm{mg} \mathrm{L}^{-1} \mathrm{BAP}+1 \mathrm{mg} \mathrm{L}^{-1} \mathrm{NAA}$ ) (Bakhtiar et al. 2016). Similarly, multiple shoot induction was observed in soybean using BAP (1.57-2 $\left.\mathrm{mg} \mathrm{L}^{-1}\right)$ (Mangena et al. 2015). Lower concentration of TDZ (cytokinin, $0.8 \mathrm{mg}$ $\mathrm{L}^{-1}$ ) was the most effective at inducing shoots in L. iberica nodal and leaf explants (Pourebad et al. 2015) showing that differential organogenesis response of same genus by different cytokinin.

In the current study, Kin also induced shooting at 0.5 $\mathrm{mg} \mathrm{L}^{-1}$ dose which represents its optimal response level but at higher concentration it inhibited the shooting response (Ashraf et al. 2014). Again nodal explants showed a better shooting ability as compared with internodes and leaves in Lamiaceae members such as $O$. gratissimum L. (Ahuja et al. 1982, Raja and Arockiasamy 2009), $O$. basilicum (Gopi and Ponmurugan 2006, Sompornpailin and Khunchuay 2016), O. viride and M. viridis L. (Siddique and Anis 2008) due to their higher totipotency (Balilashaki et al. 2015). On the other hand, leaves showed minimal regeneration potential which is contradictory to results in Salvia nemorosa L. (Skaia and Wysokinska 2004) and O. basilicum (Phippen and Simon 2000) which showed sufficient regeneration from leaves. Salvia canariens L. is another member which was regenerated from petiolar explants (Mederos-Molina Sebastiana 2004b) whereas $L$. royleana petioles failed to produce shooting response which might be due to differential totipotency of different plant genera (Condic 2014, Fehér 2019). Likewise, internodes were also unresponsive in shooting in the present study but Shasany et al. (1998) demonstrated the regenerative nature of internodal segments of $M$. arvensis $\mathrm{L}$.

Auxins were reported effective in rooting of regenerated plants in many species as they promote rooting at low concentrations. NAA was more effective in root induction and relatively stable than IAA so NAA is found in commercial rooting compound (Han et al. 2009). This is similar to the findings with $O$. sanctum (Shilpa et al. 2010), Picrorhiza (Lal et al. 1988) and Rumex crispus L. (Mahdieh et al. 2015). These effects of NAA and IAA showed direct relationship between their concentration and increase in root number and length. Lallemanta iberica and Thymus persicus (Ronniger ex Rech.f) Jalas. plantlets developed maximum roots at $1 \mathrm{mg} \mathrm{L}^{-1}$ IBA (Bakhtiar et al. 2016, Ozdemir et al. 2014). Previously, Little and MacDonald et al. (2003) reported that exogenous IAA and NAA did not promote stem growth in plants such as Pinus sylvestris L. and Picea glauca L. The current observations are contrary to the findings where exogenous auxins caused considerable increase in stem growth. Recent reports also showed that Lawsonia inermis $\mathrm{L}$. leaves and roots formation were not affected by NAA (Quainoo et al. 2014) as NAA and IAA both are less stable than IBA (Bartel et al. 2001, Han et al. 2009). The present study shows a comparison of leaves, petioles, nodes, and internode explants of Lallementia royleana for in vitro regeneration study using various types and concentrations of plant growth regulators. The best callus forming was evaluated at $1 \mathrm{mg} \mathrm{L}^{-1} \mathrm{BAP}+2 \mathrm{mg}$ $\mathrm{L}^{-1} \mathrm{IAA}$. The highest shooting and rooting were achieved from nodes at $1 \mathrm{mg} \mathrm{L}^{-1} \mathrm{BAP}+0.5 \mathrm{mg} \mathrm{L}^{-1} \mathrm{KIN}$ and $1 \mathrm{mg}$ $\mathrm{L}^{-1} \mathrm{NAA}$, respectively. Moreover, direct regeneration was significant than through callogenesis.

\section{CONCLUSION}

The present in vitro culturing method can be used for large scale propagation, producing genetically transformed plants, and conserving elite germplasm. This in vitro culturing can also be helpful in conservation approach for threatened and endangered plants. However, further work is needed to improve its callogenic ability and to evaluate the effect of various plant growth regulators on its genetic makeup. 


\section{ACKNOWLEDGEMENT}

We are thankful to National agriculture research center (NARC) Islamabad, Pakistan for providing fresh seeds for experiments.

\section{REFERENCES}

Abdulrasool, A.A., Naseer, A.A. \& Rahi, F.A. 2017. Application of seed mucilage extracted from Lallemantia royleana as a suspending agent. Iraqi Journal of Pharmaceutical Sciences 20:8-13.

Ahuja, A., Verma, M. \& Grewal, S. 1982. Clonal propagation of Ocimum species by tissue culture [drug plant]. Indian Journal of Experimental Biology 20:455-8458.

Arya, D., Patni, V. \& Kant, U. 2008. In vitro propagation and quercetin quantification in callus cultures of Rasna (Pluchea lanceolata Oliver \& Hiern.). Indian Journal of Biotechnology 7:383-387.

Ashraf, M. F., Aziz, M. A., Kemat, N. \& Ismail, I. 2014. Effect of cytokinin types, concentrations and their interactions on in vitro shoot regeneration of Chlorophytum borivilianum Sant. \& Fernandez. Electronic Journal of Biotechnology 17:275-279.

Bakhtiar, Z., Mirjalili, M.H. \& Sonboli, A. 2016. In vitro callus induction and micropropagation of Thymus persicus (Lamiaceae), an endangered medicinal plant. Crop Breeding and Applied Biotechnology 16:48-54.

Balilashaki, K., Vahedi, M. Karimi, R. 2015. In vitro Direct Regeneration from Node and Leaf Explants of Phalaenopsis cv. Surabaya. Plant Tissue Culture and Biotechnology 25:193-205.

Bartel, B., LeClere, S., Magidin, M. \& Zolman, B.K. 2001. Inputs to the active indole-3-acetic acid pool: de novo synthesis, conjugate hydrolysis, and indole-3-butyric acid b-oxidation. Journal of Plant Growth Regulation 20:198-216.

Condic, M.L. 2014. Totipotency: what it is and what it is not. Stem cells and development 23:796-812.

Dode, L.B., Bobrowski, V.L., Braga, E.J.B., Seixas, F.K. \& Schuch, M.W. 2003. In vitro propagation of Ocimum basilicum L.(Lamiaceae). Acta Scientiarum Biological Sciences 25:435-437.

Fehér, A. 2019. Callus, dedifferentiation, totipotency, somatic embryogenesis: what these terms mean in the era of molecular plant biology? Frontiers in plant science 10: 536.

Gopi, C. \& Ponmurugan, P. 2006. Somatic embryogenesis and plant regeneration from leaf callus of Ocimum basilicum L. Journal of biotechnology 126:260-264.

Hammer, Ø., Harper, D. \& Ryan, P. 2001. PAST-Palaeontological statistics. www. uv. es/ pardomv/pe/2001 1/past/pastprog/past. pdf, acessado em 25:2009.

Han, H., Zhang, S. \& Sun, X. 2009. A review on the molecular mechanism of plants rooting modulated by auxin. African Journal of Biotechnology 8(3):348-353.

Hill, K. \& Schaller, G.E. (2013). Enhancing plant regeneration in tissue culture: a molecular approach through manipulation of cytokinin sensitivity. Plant signaling \& behavior 8:212-24.

Hossain, A.S., Haq, I., Ibrahim, N. A. \& Aleissa, M.S. 2016. Callus cell proliferation from broccoli leaf slice using IBA and BAP in vitro culture: Its biochemical and antioxidant properties. Data in brief 6:214-220.

Ikeuchi, M., Sugimoto, K. \& Iwase, A. 2013. Plant callus: mechanisms of induction and repression. The Plant Cell 25:3159-3173.

Iwase, A., Mitsuda, N., Koyama, T., Hiratsu, K., Kojima, M., Arai, T., et al. 2011. The AP2/ERF transcription factor WIND1 controls cell dedifferentiation in Arabidopsis. Current Biology 21:508-514.

Krishna, H., Alizadeh, M., Singh, D., Singh, U., Chauhan, N., Eftekhari, M., et al. 2016. Somaclonal variations and their applications in horticultural crops improvement. 3 Biotech 6:54.

Kubis, S.E., Castilho, A.M., Vershinin, A.V. \& Heslop-Harrison, J.S.P. 2003. Retroelements, transposons and methylation status in the genome of oil palm (Elaeis guineensis) and the relationship to somaclonal variation. Plant molecular biology 52:69-79.

Lal, N., Ahuja, P.S., Kukreja, A.K. \& Pandey, B. 1988. Clonal propagation of Picrorhiza kurroa Royle ex Benth. by shoot tip culture. Plant cell reports 7:202-205.

Lim, Z. X., Ling, A. P. K. \& Hussein, S. 2009. Callus induction of Ocimum sanctum and estimation of its total flavonoids content. Asian Journal of Agricultural Sciences 1:55-61.

Mahajan, R., Kapoor, N. \& Singh, I. 2016. Somatic embryogenesis and callus proliferation in Picrorhiza kurroa Royle ex. Benth. Journal of Experimental Biology 4(2):201-209.

Mahdieh, M., Noori, M. \& Hoseinkhani, S. 2015. Studies of in vitro adventitious root induction and flavonoid profiles in Rumex crispus. Advances in Life Sciences 5:53-57.

Mangena, P., Mokwala, P.W. \& Nikolova, R.V. 2015. In vitro multiple shoot induction in soybean. International Journal of Agriculture and Biology 17:838-842.

Mederos-Molina, S. 2004a. In vitro callus induction and plants from stem and petiole explants of. Salvia canariensis. Plant Tissue Culture 14:167-172.

Mederos-Molina, S. 2004b. In vitro callus induction and plants from stem and petiole explants of Salvia canariensis L. Plant tissue cult 14:167-172.

Murashige, T. \& Skoog, F. 1962. A revised medium for rapid growth and bio assays with tobacco tissue cultures. Physiologia plantarum 15:473-497.

Ozdemir, F.A., Yildirim, M.U. \& Pourali Kahriz, M. 2014. Efficient micropropagation of highly economic, medicinal and ornamental plant Lallemantia iberica (Bieb.) Fisch. and CA Mey. BioMed research international 2014:1-5.

Pattnaik, S. \& Chand, P.K. 1996. In vitro propagation of the medicinal herbs Ocimum americanum L. syn. O. canum Sims.(hoary basil) and Ocimum sanctum L.(holy basil). Plant cell reports 15:846-850.

Phippen, W.B. \& Simon, J.E. 2000. Shoot regeneration of young leaf explants from basil (Ocimum basilicum L.). In Vitro Cellular \& Developmental Biology-Plant 36:250-254.

Ploetz, R., Heine, G., Haynes, J. \& Watson, M. 2002. An investigation of biological attributes that may contribute to the importance of Phytophthora capsici as a vegetable pathogen in Florida. Annals of applied biology 140:61-67.

Pourebad, N., Motafakkerazad, R., Kosari-Nasab, M., Akhtar, N. F. \& Movafeghi, A. 2015. The influence of TDZ concentrations on in vitro growth and production of secondary metabolites by the shoot and callus culture of Lallemantia iberica. Plant Cell, Tissue and Organ Culture (PCTOC) 122:331-339.

Quainoo, A., Kabrir, K. \& Mahunu, G. 2014. Effect of naphthalene acetic acid on rooting and shoot growth of Lawsonia inermis 2:50-52.

Rahman, N., Rosli, R., Kadzimin, S. \& Hakiman, M. 2019. Effects of auxin and cytokinin on callus induction in Catharanthus roseus (L.) G. Don. Fundamental and Applied Agriculture 4:928-932.

Raja, H. D. \& Arockiasamy, D. 2009. In vitro Propagation of Mentha viridis L. from Nodal and Shoot tip Explants. Plant Tissue Culture and Biotechnology 18:1-6.

Razavi, S.M.A., Cui, S.W. \& Ding, H. 2016. Structural and physicochemical characteristics of a novel water-soluble gum from Lallemantia royleana seed. International journal of biological macromolecules 83:142-151.

Saker, M., Bekheet, S., Taha, H., Fahmy, A. \& Moursy, H. 2000. Detection of somaclonal variations in tissue culture-derived date palm plants using isoenzyme analysis and RAPD fingerprints. Biologia Plantarum 43:347-351.

Samantaray, S., Kumar Bishoyi, A. \& Maiti, S. 2013. Plant regeneration from callus cultures of Vitex trifolia (Lamiales: Lamiaceae): a potential medicinal plant. Revista de biologia tropical 61:1083-1094.

Shilpa, K., Selvakkumar, C., Senthil, A.K. \& Lakshmi, B.S. 2010. In vitro root culture of Ocimum sanctum $\mathrm{L}$. and evaluation of its free radical scavenging activity. Plant Cell, Tissue and Organ Culture (PCTOC) 101:105-109. 
Siddique, I. \& Anis, M. 2008. An improved plant regeneration system and ex vitro acclimatization of Ocimum basilicum L. Acta physiologiae plantarum 30:493-499.

Skoog, F.Miller, C. (1957). Chemical regulation of growth and organ formation in plant tissues cultured In Vitro. Symposiaof the Society for Experimental Biology 11:118-131.

Sompornpailin, K.Khunchuay, C. 2016. Synergistic effects of BAP and kinetin media additives on regeneration of vetiver grass ('Vetiveria zizanioides' L. Nash). Australian Journal of Crop Science 10:726.
Sujana, P. \& Naidu, C. 2011. Indirect Plant Regeneration from Leaf Explants of Mentha piperita (L.) â€"An Important Multipurpose Medicinal Plant. Journal of phytology 3:19-22.

Tawfik, A.A. Mohamed, M.F. 2007. Regeneration of salvia (Salvia officinalis L.) via induction of meristematic callus. In Vitro Cellular and Developmental Biology-Plant 43:21-27.

Toma, I., Toma, C. \& Ghiorghita, G. 2004. Histo-anatomy and in vitro morphogenesis in Hyssopus officinalis L.(Lamiaceae). Acta Botanica Croatica 63:59-68. 


\section{SUPPLEMENTARY DATA}

Table 1. Callus induction response of different explants on (Murashige and Skoog 1962) MS media after 5 weeks with different plant growth regulators. Callus induction media (CIM) have been prepared by addition of different concentrations of NAA, IAA, BAP, combination of BAP with IAA and 2,4-D with NAA. PGRs $=$ Plant growth regulators, Conc $=$ Concentration, $\mathrm{CIM}=$ Callus induction media, NAA =: Naphthalene acetic acid, IAA Indole acetic acid, “+” stand for positive response while "-" represent no response.

\begin{tabular}{|c|c|c|c|c|c|c|c|c|c|c|c|}
\hline \multirow{2}{*}{ Media Type } & \multirow{2}{*}{ PGRs } & \multirow{2}{*}{$\begin{array}{l}\text { Conc. } \\
\left(\mathrm{mgL}^{-1}\right)\end{array}$} & \multirow{2}{*}{ Explant } & \multicolumn{5}{|c|}{ Weekly Response } & \multirow{2}{*}{ Texture } & \multirow{2}{*}{ Color } & \multirow{2}{*}{$\begin{array}{c}\text { Callus } \\
\text { Induction \% }\end{array}$} \\
\hline & & & & 1 & 2 & 3 & 4 & 5 & & & \\
\hline \multirow[t]{3}{*}{ CIM0 } & - & - & Nodes & - & - & - & - & - & - & - & - \\
\hline & & & Internodes & - & - & - & - & - & - & - & - \\
\hline & & & Leaves & - & - & - & - & - & - & - & - \\
\hline \multirow[t]{3}{*}{ CIM1 } & NAA & 0.5 & Nodes & - & - & + & - & - & Fragile & Brown & 70 \\
\hline & & & Internodes & - & - & - & - & - & - & - & - \\
\hline & & & Leaves & - & - & - & - & - & - & - & - \\
\hline \multirow[t]{3}{*}{ CIM2 } & NAA & 1 & Nodes & - & + & + & - & - & Fragile & Green & 50 \\
\hline & & & Internodes & - & + & + & - & - & Fragile & White & 90 \\
\hline & & & Leaves & - & - & - & - & - & - & - & - \\
\hline \multirow[t]{3}{*}{ CIM3 } & NAA & 2 & Nodes & - & + & - & - & - & Fragile & Green & 90 \\
\hline & & & Internodes & - & + & ++ & ++ & - & Fragile & Green & 90 \\
\hline & & & Leaves & - & - & - & - & - & - & - & - \\
\hline \multirow[t]{3}{*}{ CIM4 } & IAA & 0.5 & Nodes & - & + & + & - & - & Fragile & Brown & 50 \\
\hline & & & Internodes & + & - & - & - & - & Fragile & Brown & 40 \\
\hline & & & Leaves & - & - & - & - & - & - & - & - \\
\hline \multirow[t]{3}{*}{ CIM5 } & IAA & 1.0 & Nodes & - & - & - & - & - & - & - & - \\
\hline & & & Internodes & - & - & - & - & - & - & - & - \\
\hline & & & Leaves & - & - & - & - & - & - & - & - \\
\hline \multirow[t]{3}{*}{ CIM6 } & IAA & 2 & Nodes & - & + & - & - & - & Fragile & Brown & 40 \\
\hline & & & Internodes & - & - & - & - & - & - & - & - \\
\hline & & & Leaves & - & - & - & - & - & - & - & - \\
\hline \multirow[t]{3}{*}{ CIM7 } & BAP & 0.5 & Nodes & - & - & - & - & - & - & - & - \\
\hline & & & Internodes & - & - & - & - & - & - & - & - \\
\hline & & & Leaves & - & - & - & - & - & - & - & - \\
\hline \multirow[t]{3}{*}{ CIM8 } & BAP & 1.0 & Nodes & - & - & - & - & - & - & - & - \\
\hline & & & Internodes & - & - & - & - & - & - & - & - \\
\hline & & & Leaves & - & - & - & - & - & - & - & - \\
\hline \multirow[t]{3}{*}{ CIM9 } & BAP & 2.0 & Nodes & - & - & - & - & - & - & - & - \\
\hline & & & Internodes & - & - & - & - & - & - & - & - \\
\hline & & & Leaves & - & - & - & - & - & - & - & - \\
\hline \multirow[t]{3}{*}{ CIM 10} & $\mathrm{BAP}+\mathrm{IAA}$ & $0.5+1$ & Nodes & + & + & - & - & - & Fragile & Green & 90 \\
\hline & & & Internodes & - & + & + & - & - & Fragile & Green & 60 \\
\hline & & & Leaves & - & - & - & - & - & - & - & - \\
\hline \multirow[t]{3}{*}{ CIM 11} & $\mathrm{BAP}+\mathrm{IAA}$ & $1+2$ & Nodes & ++ & ++ & ++ & - & - & Fragile & Green & 100 \\
\hline & & & Internodes & ++ & ++ & ++ & - & - & Fragile & Green & 100 \\
\hline & & & Leaves & - & - & - & - & - & - & - & - \\
\hline \multirow[t]{3}{*}{ CIM 12} & $2,4-\mathrm{D}+\mathrm{NAA}$ & $2+1$ & Nodes & + & + & + & & - & Fragile & Green & 90 \\
\hline & & & Internodes & + & + & ++ & ++ & - & Fragile & Green & 90 \\
\hline & & & Leaves & - & - & + & ++ & - & Fragile & $\begin{array}{l}\text { Pale } \\
\text { Green }\end{array}$ & 20 \\
\hline CIM 13 & $2,4-\mathrm{D}+\mathrm{NAA}$ & $1+2$ & Nodes & + & + & + & ++ & - & Fragile & Green & 90 \\
\hline & & & Internodes & - & - & + & + & - & Fragile & Green & 80 \\
\hline & & & Leaves & - & - & - & - & - & Fragile & & 0 \\
\hline
\end{tabular}


Table 2. Analysis of variance (ANOVA) for percentage of callus induction on MS media supplemented with naphthalene acetic acid (NAA), indole acetic acid (IAA), benzyl aminopurine (BAP), BAP + indole acetic acid (IAA) and 2, 4 Dichlorophenoxyacetic acid (2, 4-D) + NAA for nodes, internodes and leaf explants. The analysis was performed using PAST software.

\begin{tabular}{lccccc}
\hline Source of variation & SS & df & Mean square & F & $\boldsymbol{p}$ (same) \\
\hline Between groups & 27134.6 & 7 & 3876.37 & 3.42 & 0.002625 \\
Within groups & 108800 & 96 & 1133.33 & \\
Total & 135935 & 103 & & & \\
\hline
\end{tabular}

df: degree of freedom, F: F test value, $p$ : significant value, SS: Sum of squares.

Table 3. Shoot induction on MS (Murashige and Skoog 1962)media having different concentrations of benzyl aminopurine (BAP) and kinetin (KIN), $\mathrm{S} . \mathrm{N}=$ Serial number, PGRs = Plant growth regulators, BAP = Benzyl amino purine, "-" = No hormone present, "S" + stands for shooting media.

\begin{tabular}{ccccc}
\hline S. $\mathbf{N}$ & Media Code & PGRs & Concentration (mg/l) & \% \\
\hline 1 & S0 & - & - & 0 \\
2 & S1 & BAP & 0.5 & 0 \\
3 & S2 & BAP & 1 & 80 \\
4 & S3 & BAP & 2 & 0 \\
5 & S4 & BAP & 4 & 0 \\
6 & S5 & Kinetin & 0.5 & 60 \\
7 & S6 & Kinetin & 2 & 20 \\
8 & S7 & Kinetin & 2 & 0 \\
9 & S8 & Kinetin & 4 & 20 \\
\hline
\end{tabular}

Table 4. Analysis of variance (ANOVA) for shooting on MS (Murashige and Skoog 1962) media supplemented with benzyl aminopurine (BAP) and kinetin (Kin). $p$ value is higher than 0.05 showing a non-significant value demonstrating no significance difference observed between BAP and KIN treatments.

\begin{tabular}{lcccccc}
\hline Source of Variation & SS & df & MS & F & $p$-value & F crit \\
\hline Between Groups & 40 & 1 & 40 & 0.042553 & 0.841722 & 5.317655 \\
Within Groups & 7520 & 8 & 940 & & & \\
Total & 7560 & 9 & & & & \\
\hline
\end{tabular}

$\mathrm{SS}=$ Sum of Squares, $\mathrm{df}=$ degree of freedom, $\mathrm{MS}=$ Mean square between groups, $\mathrm{F}=\mathrm{F}$ test value, $p=$ significant value, $\mathrm{F}$ crit $=\mathrm{F}$ critical value

Table 5. Root induction on (Murashige and Skoog 1962) MS media supplemented with different concentrations of concentrations of NAA and IAA plant growth regulators. S.N = Serial number, PGRs = Plant growth regulators, NAA = Naphthalene acetic acid, IAA = Indole acetic acid, "“" = No hormone present, $\mathrm{e}$ "R" = stand for rooting media.

\begin{tabular}{ccccc}
\hline S.N & Media code & PGR's & Concentration $\left(\mathbf{m g} \mathbf{L}^{-1}\right)$ & $\%$ \\
\hline 1 & R0 & - & - & 0 \\
2 & R1 & NAA & 0.5 & 9 \\
3 & R2 & NAA & 1 & 24 \\
4 & R3 & NAA & 2 & 9 \\
5 & R4 & IAA & 0.5 & 4 \\
6 & R5 & IAA & 1 & 0 \\
7 & R6 & IAA & 2 & 11 \\
\hline
\end{tabular}

Table 6. Analysis of variance (ANOVA) for shooting on MS (Murashige and Skoog 1962) media supplemented with naphthalene acetic acid (NAA) and indole acetic acid (IAA). The analysis was performed using PAST software. $p$ value is higher than 0.05 indicating no significance difference observed between treatments.

\begin{tabular}{lcccccc}
\hline Source of Variation & SS & df & MS & F & $p$-value & F crit \\
\hline Between Groups & 121.5 & 1 & 121.5 & 2.292453 & 0.204568 & 7.708647 \\
Within Groups & 212 & 4 & 53 & & & \\
Total & 333.5 & 5 & & & & \\
\hline
\end{tabular}

$\mathrm{SS}=$ Sum of Squares, $\mathrm{df}=$ degree of freedom, $\mathrm{MS}=$ Mean square between groups, $\mathrm{F}=\mathrm{F}$ test value, $p=$ significant value, $\mathrm{F}$ crit $=\mathrm{F}$ critical value. 